\title{
Educational Concept for Citizens' Awareness Towards Technological Advancements for a Sustainable Society-Introducing a Concept for Interactive Societal Learning on Hydrogen and Carbon
}

\author{
Robert Obenaus-Emler, Markus Lehner, Mariaelena Murphy, and Corina Pacher
}

Montanuniversität Leoben, Leoben, Austria

Received April 8, 2021; accepted April 29, 2021; published online June 9, 2021

\begin{abstract}
Hydrogen is a key element of our everyday life. It is an irreplaceable feedstock for the production of fertilisers, fuels, and chemicals. From a scientific point of view, hydrogen can additionally play a major role in future energy systems and help to decarbonise the sectors industry, heat and power generation as well as transport and mobility. Thus, it can contribute to the energy transition and the reduction of greenhouse gas emissions at a large scale and consequently help to mitigate climate change. It is, therefore, a key building block to reach the remarkably challenging goals recently stated in the European Green Deal. Therefore, the overarching question is whether hydrogen can measure up to the great expectations raised and how creating public awareness and education can contribute in achieving a social license to operate for emerging new technological developments in this context. Education is not solely an instrument for academic excellence but also a powerful tool to raise public awareness with regard to the development of new technologies. While the main goal of the pyrolysis project is to research sustainable means of hydrogen production, the project also considers its role within the community as a positive side effect. To safeguard and promote the scientific social licence to operate, an educational programme will be additionally developed to raise civic awareness and grant access to the developments made in the project in a learning lab, which will have open access for schools and the general public.
\end{abstract}

Keywords: Hydrogen, Pyrolysis, Awareness raising, Sustainability, Education

\footnotetext{
R. Obenaus-Emler ( $\square)$

Montanuniversität Leoben,

Franz Josef-Straße 18,

8700 Leoben, Austria

emler@unileoben.ac.at
}

Bildungskonzept zur Bürgersensibilisierung technologischer Fortschritte für eine nachhaltige Gesellschaft - Einführung eines Konzepts für interaktives gesellschaftliches Lernen zu Wasserstoff und Kohlenstoff

Zusammenfassung: Wasserstoff ist ein Schlüsselelement unseres täglichen Lebens. Er ist ein unersetzlicher Rohstoff für die Herstellung von Düngemitteln, Kraftstoffen und Chemikalien. Aus wissenschaftlicher Sicht kann Wasserstoff zudem eine wichtige Rolle in zukünftigen Energiesystemen spielen und zur Dekarbonisierung der Sektoren Industrie, Wärme- und Stromerzeugung sowie Verkehr und Mobilität beitragen. Damit kann er einen Beitrag zur Energiewende und zur Reduktion der Treibhausgasemissionen in großem Umfang leisten und somit helfen, den Klimawandel abzumildern. Wasserstoff ist daher ein wichtiger Baustein, um die bemerkenswert anspruchsvollen Ziele zu erreichen, die kürzlich im europäischen Green Deal festgelegt wurden. Die übergreifende Frage ist daher, ob Wasserstoff den großen Erwartungen gerecht werden kann und wie die Schaffung eines öffentlichen Bewusstseins und Bildung dazu beitragen können, eine gesellschaftliche Lizenz für neue technologische Entwicklungen in diesem Kontext zu erhalten. Bildung ist nicht nur ein Instrument für akademische Exzellenz, sondern auch ein mächtiges Werkzeug zur Sensibilisierung der Öffentlichkeit im Hinblick auf die Entwicklung neuer Technologien. Das Hauptziel des Pyrolyseprojekts ist die Erforschung nachhaltiger Mittel zur Wasserstofferzeugung, darüber hinaus betrachtet das Projekt als positiven Nebeneffekt auch die Rolle innerhalb der Gemeinschaft. Zur Sicherung und Förderung der wissenschaftlichen Zustimmung innerhalb einer breiten Öffentlichkeit wird ein Bildungsprogramm entwickelt, um das öffentliche Bewusstsein zu schärfen und Zugang zu den Entwicklungen des Projekts in einem Lernlabor zu ermöglichen, das für Schulen und die allgemeine Öffentlichkeit offen zugänglich ist. 
Schlüsselwörter: Wasserstoff, Pyrolyse,

Bewusstseinsbildung, Nachhaltigkeit, Bildung

\section{Introduction}

In July 1955 Dwight Eisenhower, president of the United States of America, publicly announced the intent to launch artificial satellites into space. Only some days later the Soviet Union responded by declaring the exact same target for the near future. The following years are known as the 'space race' that ultimately peaked on July 20, 1969, when the US Apollo 11 mission successfully landed on the moon and Neil Armstrong left the first human footprint in the lunar soil.

When the Soviet Union launched the Sputnik in 1957, it brought about great panic in the US on both governmental and societal fronts. The result of this saw the US congress passing the National Defense Education Act (NDEA). The act itself presented a package of one billion dollars to advance high-quality teaching and learning in science, mathematics, and languages. This had a profound impact on education curricula, which continued to develop and provide action for excellent schooling in the subsequent decades.

Although the 'space race' itself was an extraordinary era of technological advancement, the side effects of such endeavours show the connectivity and innovation developments that are created as either a direct or indirect result.

Education is not solely an instrument for academic excellence but also a powerful tool to raise public awareness with regard to the development of new technologies. The main goal of the pyrolysis project is to research sustainable means of hydrogen production. As a positive side effect, the project also considers its role within the community. To safeguard and promote the scientific social licence to operate, an educational programme will be developed to raise civic awareness and grant access to the developments made in the project in a learning lab, which will have open access for schools and the general public.

Recently an enormous hype related to hydrogen has made its way from the scientific community to the general public. Unfortunately, a great contribution to this lively discussion comes from outside the scientific community resulting in many misconceptions related to the production, distribution, and application of hydrogen. While politically hydrogen is viewed as a magic panacea to tackle the climate crises, the energy crises, future industrial production, and future mobility needs right off the reel, others are afraid of its application due to the low explosibility limit. In fact, many questions related to the production and application of hydrogen have to be addressed and properly answered on a scientific level in order to ensure the implementation of environmentally sustainable and economically feasible solutions in the context of a future resilient industry, infrastructure, and society.

Although mostly unknown to the majority of people, even today hydrogen is a key element of our everyday life. It is an irreplaceable feedstock for the production of fertilisers, fuels, and chemicals. From a scientific point of view, hydrogen can additionally play a major role in future en- ergy systems and help to decarbonise the sectors industry, heat and power generation as well as transport and mobility. Thus, it can contribute to the energy transition and the reduction of greenhouse gas emissions at a large scale and consequently help to mitigate climate change. It is, therefore, a key building block to reach the remarkably challenging goals recently stated in the European Green Deal. Besides specific questions related to the distribution of hydrogen and its individual future applications, however, two inevitable questions need to be answered first: (1) How can hydrogen be produced sustainably with a minimal $\mathrm{CO}_{2-}$ footprint at large scales and (2) what is the timeframe for the implementation of this technology at a reasonable scale to actually have an impact on the aforementioned key sustainability issues? In other words, can hydrogen measure up to the great expectations raised and how can creating public awareness and education contribute in achieving a social license to operate for emerging new technological developments in this context?

\section{Present and Future Role of Hydrogen -A Short Overview}

Presently hydrogen is almost exclusively used as a feedstock in the chemical and petro-chemical industry to produce other materials due to its properties. The annual consumption of hydrogen in the European Union is close to 11 mio. metric tons, corresponding to an energy amount of roughly 325 TWh (Fig. 1). Most of the hydrogen is used in the petro-chemical industry for hydrotreating of crude oil to remove sulphur and other contaminants as well as hydrocracking to convert heavy fuel oil components into usable products (e.g. fuels). In the chemical industry, hydrogen is mainly used in the Haber-Bosch process for the production of ammonia that is predominantly converted to fertilisers. A smaller share of hydrogen (about $10 \%$ ) is used for the production of methanol, which acts as a platform chemical for the subsequent production of many other products [1]. All other fields of application (e.g. metallurgy, production of glass, mobility, production of semiconductors) are presently of minor importance but have great potential in the near future.

Fig. 2 summarises future applications of hydrogen additionally including the areas of mobility and transport, high quality heat for industry and buildings, the coupling with the gas grid, and further applications as feedstock in the (petro-)chemical industry and for metallurgical processes (Fig. 2). The annual demand of hydrogen in the European Union is estimated to increase to roughly 70 mio. metric tons by 2050 . This corresponds to roughly $2250 \mathrm{TWh}$ of energy, which is almost one tenth of the total primary energy demand today.

In 2015, the European Union emitted about 3500 mio. metric tons of $\mathrm{CO}_{2}$ into the atmosphere. In order to keep global warming well below $2^{\circ} \mathrm{C}$ above preindustrial levels (2 degree scenario-2DS), energy-related $\mathrm{CO}_{2}$ emissions in the European Union must be reduced to less than 770 mio. metric tons by 2050 [2]. In a reference technology scenario (RTS), considering present commitments by countries to 


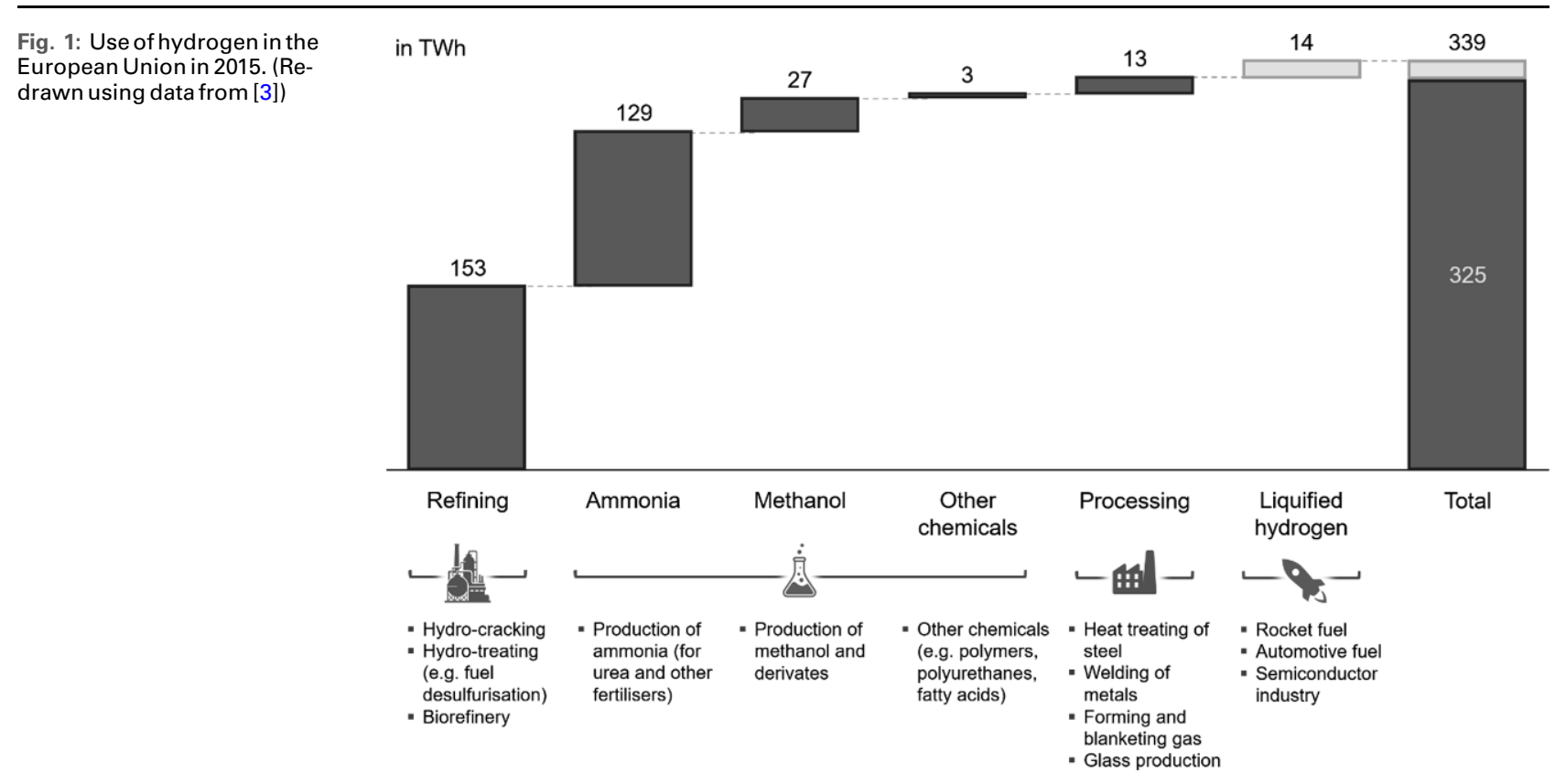

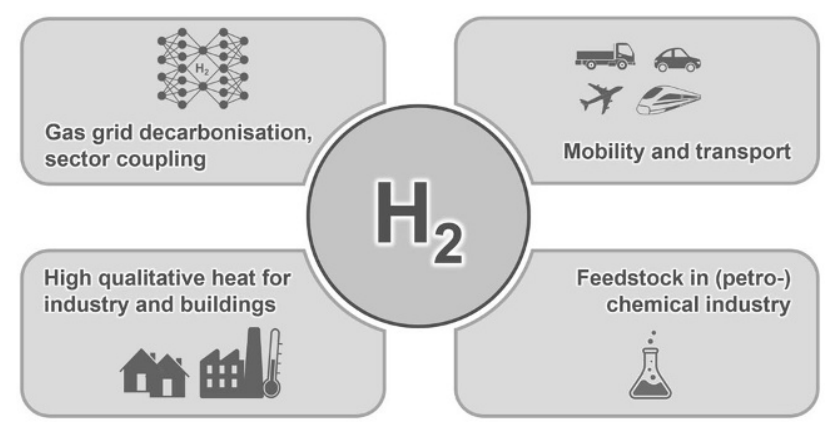

Fig. 2: Future applications of hydrogen

limit emissions and improve energy efficiency, the EU's $\mathrm{CO}_{2}$ emissions will be reduced by roughly 1700 mio. metric tons by 2050. According to the Hydrogen Roadmap Europe [3] the use of hydrogen can contribute an additional reduction of roughly 560 mio. metric tons of $\mathrm{CO}_{2}$ by 2050 . Therefore, hydrogen can potentially close up to $50 \%$ of the gap between the RTS and the 2DS. Yet, this substantial contribution of hydrogen to the reduction of $\mathrm{CO}_{2}$ emissions can only be achieved if hydrogen can be produced (1) with a minimal $\mathrm{CO}_{2}$-footprint and (2) at large scales.

\subsection{Hydrogen Production-State of the Art}

The large amounts of hydrogen used today are almost exclusively produced from fossil resources: $48 \%$ from natural gas, $30 \%$ from crude oil, and $18 \%$ from coal. Only about $4 \%$ of hydrogen is produced by electrolysis, of which only one fourth is produced by water electrolysis - the main share is generated as a by-product from chlor-alkali-electrolysis [4].

At present, the large scale production of hydrogen is done by converting fossil hydrocarbons into a synthesis gas by partial oxidation or steam methane reforming. This autothermal process is explained here by using methane
$\left(\mathrm{CH}_{4}\right)$, the main component of natural gas, as an example. The main chemical reaction for the steam methane reforming is endotherm with a standard reaction enthalpy of $206.2 \mathrm{~kJ}$ per mol of methane:

$$
\mathrm{CH}_{4}+\mathrm{H}_{2} \mathrm{O} \leftrightarrow \mathrm{CO}+3 \mathrm{H}_{2} \quad \Delta \mathrm{H}_{\mathrm{R}}^{0}=206.2 \mathrm{~kJ} / \mathrm{mol}
$$

The required energy for this reaction is normally generated by partial oxidation of natural gas according to:

$$
2 \mathrm{CH}_{4}+\mathrm{O}_{2} \leftrightarrow 2 \mathrm{CO}+4 \mathrm{H}_{2} \quad \Delta \mathrm{H}_{\mathrm{R}}^{0}=-71 \mathrm{~kJ} / \mathrm{mol}
$$

In order to increase the hydrogen yield, the resulting $\mathrm{CO}$ in the synthesis gas will be further processed according to the water-gas shift reaction in a subsequent process step:

$$
\mathrm{CO}+\mathrm{H}_{2} \mathrm{O} \leftrightarrow \mathrm{CO}_{2}+\mathrm{H}_{2} \quad \Delta \mathrm{H}_{\mathrm{R}}^{0}=-41.2 \mathrm{~kJ} / \mathrm{mol}
$$

The resulting $\mathrm{CO}_{2}$ is separated from the product gas and released into the atmosphere. As a result, for each kilogram of hydrogen, roughly $12 \mathrm{~kg}$ of $\mathrm{CO}_{2}$ are emitted [5]. Consequently, this production route can only deliver hydrogen with a reduced carbon footprint if the resulting $\mathrm{CO}_{2}$ is not emitted but captured.

\subsection{Possible Future Pathways for the Production of Hydrogen - State of the Art}

As shown above, the future hydrogen production has to rely on technology with a minimal $\mathrm{CO}_{2}$-footprint. Fig. 3 summarises possible future pathways that are currently under further investigation and development. These technologies rely on different resources, are based on different conversion technologies, and require different methods to reduce the overall $\mathrm{CO}_{2}$-footprint of the process. The main principles and technological aspects will be briefly outlined. 


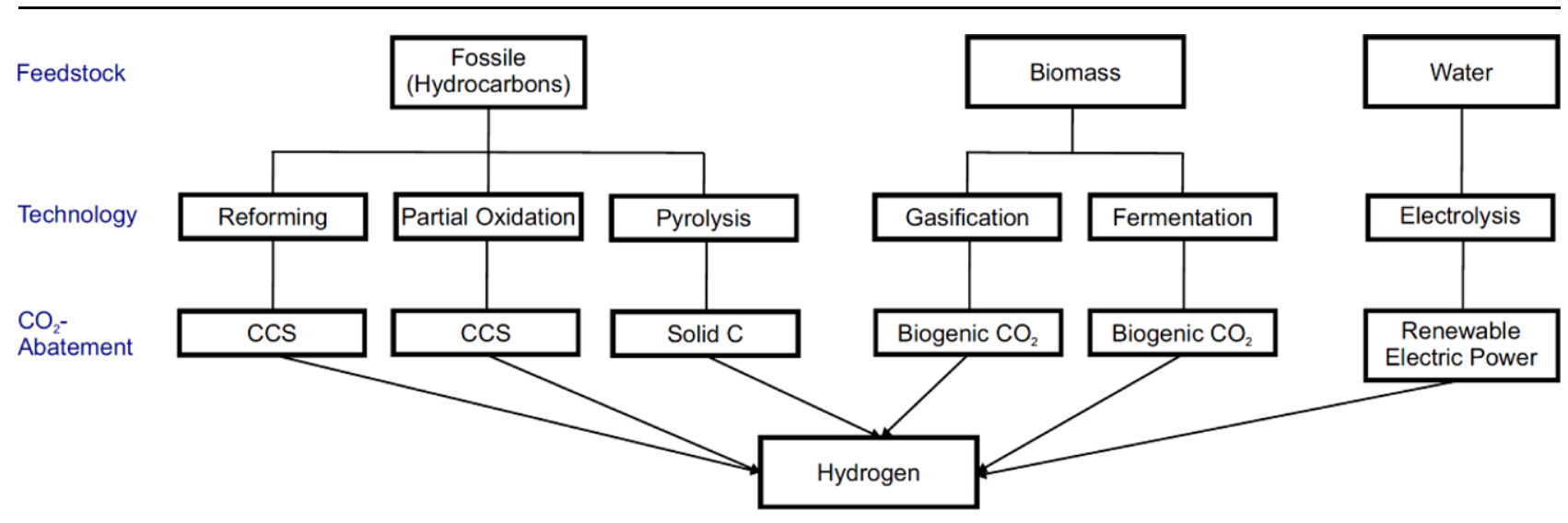

Fig. 3: Pathways to hydrogen production with reduced $\mathrm{CO}_{2}$-footprint

\subsubsection{Hydrogen From Water Via Electrolysis}

Hydrogen is generally referred to as 'green hydrogen' if it is produced from water by electrolysis using renewable electrical energy. Theoretically the decomposition of water into hydrogen and oxygen requires $39.4 \mathrm{kWh}$ for one kilogram of hydrogen at standard temperature and pressure. In principle, three different technologies with different technological readiness levels (TRL) and specifications can be distinguished: Alkaline, high-pressure water electrolysis $(A E)$, polymer electrolyte membrane electrolysis (PEM), and solid oxide electrolyser cell (SOEC). Alkaline high-pressure electrolysis has the highest TRL followed by PEM (currently at demonstration scale of several MWs), while SOEC is only available at smaller (pilot) scale.

Further developments are supposed to increase the efficiency of electrolysis by up to $80 \%$ by 2050 , which results in a specific energy consumption of roughly $50 \mathrm{kWh}$ per kilogram of hydrogen. Consequently, the production of the forecasted hydrogen demand of the European Union (70 mio. metric tons) would require roughly $3500 \mathrm{TWh}$ of electrical energy.

The presently available energy mix in the European Union has a $\mathrm{CO}_{2}$-footprint of roughly $450 \mathrm{~g} \mathrm{CO}_{2} / \mathrm{kWh}_{\mathrm{el}}$ [6]. As a result, the production of $1 \mathrm{~kg}$ of hydrogen by water electrolysis would result in $\mathrm{CO}_{2}$ emissions in excess of $22 \mathrm{~kg}$; almost twice as much as from steam methane reforming. Due to the relatively high specific energy consumption for hydrogen production by water electrolysis, the required electrical energy has to be exclusively available from renewable sources.

The amount of renewable electrical energy produced in the European Union in 2019, was roughly 1470 TWh, already $\sim 37 \%$ of the total electrical energy requirement. Although the share of renewable electrical energy will still increase in the coming decades, it is quite obvious that the vast amount of energy required for the production of green hydrogen via electrolysis will not be readily available. Thus, the contribution of electrolysis to hydrogen production is, and will remain, limited.

\subsubsection{Hydrogen From Biomass}

In biogas plants, organic material can be converted into biogas by fermentation. The resulting biogas is mainly composed of methane ( 50 to $80 \%$ ) and $\mathrm{CO}_{2}$ that can be converted to hydrogen in a subsequent reforming step. Thus, biomass can be used to produce hydrogen with a reduced $\mathrm{CO}_{2}$-footprint. While the fermentation of biomass to biogas is a state-of-the-art technology, the reforming of biogas is still under development and is not industrially scaled yet [7]. An alternative is the gasification of biomass in the presence of water vapour that results in a hydrogen-rich gas. This synthetic gas can be used directly as a reduction agent (e.g. in the steel production) or further processed to a hydrogen product via the water gas-shift reaction and subsequent removal of $\mathrm{CO}_{2}$.

When using biomass as a feedstock for hydrogen production, the $\mathrm{CO}_{2}$ emissions are not considered, since they are incorporated into the plants directly from the atmosphere. Only a small $\mathrm{CO}_{2}$-footprint (originating from production and transport of the biomass as well as the conversion infrastructure and utilities) can be attributed to the resulting hydrogen. However, the unfavourable ratio of hydrogen to carbon in biomass, in combination with their finite availability and current use, limits their contribution to hydrogen with a reduced $\mathrm{CO}_{2}$-footprint.

\subsubsection{Hydrogen From Fossil Resources With Subsequent Carbon Capture and Storage}

As already mentioned above, hydrogen with a reduced $\mathrm{CO}_{2}$-footprint can be produced from fossil resources via steam reforming or partial oxidation combined with a subsequent capture and storage of carbon. In addition to the high availability of fossil resources, the technological readiness and scalability of this approach are a major benefit and would allow the production of hydrogen with reduced $\mathrm{CO}_{2}-$ footprint at large scales. Yet, the options for a permanent storage of large quantities of $\mathrm{CO}_{2}$ are presently limited due to major concerns, especially related the long-term stability of such storage facilities. Most promising storage options are based on the injection of $\mathrm{CO}_{2}$ in depleted oil or gas deposits, mainly off-shore [8]. Although some projects for 
carbon storage are presently under development in the European Union, a large storage capacity will not be available in the near future.

\subsubsection{Hydrogen From Fossil Resources by Pyrolysis}

An alternative production route based on fossil resources that has recently attracted attention is methane pyrolysis. Here, methane $\left(\mathrm{CH}_{4}\right)$ is decomposed into its components, hydrogen and carbon, at temperatures of roughly above $800^{\circ} \mathrm{C}$ in the absence of oxygen. Hence, the process has no direct $\mathrm{CO}_{2}$ emissions but delivers solid carbon, a valuable product [9]. The main chemical reaction for the decomposition of methane is endotherm with a standard reaction enthalpy of $74.9 \mathrm{~kJ}$ per mol of methane:

$$
\mathrm{CH}_{4} \leftrightarrow \mathrm{C}+2 \mathrm{H}_{2} \quad \Delta \mathrm{H}_{\mathrm{R}}^{0}=74.9 \mathrm{~kJ} / \mathrm{mol}
$$

This corresponds to an energy input of $18.6 \mathrm{MJ}$ for one kilogram of hydrogen at standard temperature and pressure, which is only $13 \%$ compared to water electrolysis.

The decomposition of methane can be accomplished thermally or assisted by certain catalysts, which generally allows for a lower process temperature. At lab scale various technologies have been studied: numerous plasma reactor technologies, moving bed or fluidised bed reactors as well as liquid salts or metal-based melts. The results indicate that the specific energy input for methane decomposition at industrial scale is roughly only one fourth compared to water electrolysis. If the energy can be supplied from renewable resources, the hydrogen production via methane pyrolysis has a relatively small $\mathrm{CO}_{2}$-footprint [10].

As stated above, methane pyrolysis delivers solid carbon as a valuable product. Depending on the process technology as well as process parameters, different allotropes of carbon may form. The type and quality of the resulting carbon govern the valorisation options. Potential large volume applications of solid carbon include the use of carbon in agriculture and the construction industry. Furthermore, the carbon can be used in special products (e.g. electrodes) or high-tech applications like supercapacitors or graphene. The valorisation of the solid carbon also contributes to the reduction of hydrogen production costs. A sustainable hydrogen production by methane pyrolysis, however, needs to be based on the complete and reasonable utilisation of carbon in sustainable applications. Additionally, some applications show the potential of a positive contribution to mitigate climate change.

Presently, the main disadvantage of methane pyrolysis is the low technology readiness level of existing technologies. Additionally, the scalability and long-term stability of these technologies is not yet sufficient for a largescale industrial application for the production of hydrogen. The Montanuniversität Leoben presently works on the evaluation of different technologies with respect to scalability and stability of the process in order to further develop a promising technology to pilot and demo scale. Additionally, further developments focus on a minimal overall material footprint of the pyrolysis technology as well as com- plete valorisation of the carbon product in sustainable applications.

\subsection{Conclusion for Future Hydrogen Production at Large Scale}

Although the availability of renewable electrical energy will still increase in the coming decades, only a limited amount will be accessible for the production of hydrogen by water electrolysis, since electrical energy will additionally be required for other emerging technologies with a reduced $\mathrm{CO}_{2}-$ footprint (e.g. electromobility). Consequently, the available energy has to be used efficiently until the enormous amounts for the production of hydrogen by water electrolysis at sufficiently large scale can be supplied. The pyrolysis of natural gas can act as a bridging technology to supply hydrogen with a reduced $\mathrm{CO}_{2}$-footprint, in parallel to water electrolysis where a surplus of renewable electrical energy is available. The resulting carbon is a valuable second product that can additionally contribute to mitigate climate change. Furthermore, the existing gas infrastructure and availability enable the supply of hydrogen using decentralised pyrolysis units connected to the gas gird. Future developments could also enable the use of biogas as a precursor for pyrolysis, which would result in a technology with a negative $\mathrm{CO}_{2}$-footprint

Although the pyrolysis of natural gas has become a potential candidate for hydrogen production at large scale in the scientific community, the awareness in the general public is highly limited. Since the pyrolysis of natural gas is based on fossil resources, a certain opposition to this technology still exists, even though the $\mathrm{CO}_{2}$-footprint of the produced hydrogen is by far lower than that of steam methane reforming. Additionally, further understanding of the sustainability potential of certain applications of solid carbon needs to be disseminated to further gain societal support for the implementation of this technology in the near future.

The aforementioned research fields related to hydrogen are an essential part of the sustainability strategy of the Montanuniversität Leoben. As part of this long-term strategy, the efforts are accordingly aimed at the systematic integration of sustainability principles both in the organisational structure, in the teaching and learning culture, and in the 3rd mission in order to make a significant contribution to the achievement of the United Nations (UN) Agenda 2030. In order to come closer to this goal, holistic awareness raising and the active collaboration of the knowledge triangle of education, (industrial) research, and society are required. Mora et al. (2018) state that Higher Education Institutions (HEIs) play a pivotal role in education for sustainability as they contribute to the production and dissemination of knowledge, values, skills, and subsequently competencies for the next generations. In Sect. 3 below, the possibilities of raising awareness in engineering education is discussed in more detail [11]. 


\section{Awareness Raising for a Sustainable Society}

Nowadays, in our fast-paced world professional education, teaching, and learning must continuously be realigned to recent developments, trends, or requirements by considering a multitude of internal as well as external influencing factors. In order to ensure the shift towards a transformational society, the continuous adaptation of educational initiatives is essential [12]. Moreover, the transitions themselves are becoming more differentiated, individual, and risky within the framework of a transformational society. Individualisation and de-standardisation of educational initiatives are the keywords of today's society. In general, transformative learning processes are needed to be able to professionally accompany the social changes and shifts within these transformation processes. The main aim of the transformative learning approach is the evolution of the ability to act - both individually and collectively - from both a social and political perspective. This implies a change, or further development, of changes in all situations in life. In particular, Mezirow refers to the respective learning outcomes and investigates the question of how learning can lead to a transformation of previous attitudes, judgements, opinions, views, and more in adults to develop into a critical, autonomous individual capable of acting and judging. Hence, the statement 'dare to use your own mind' will become an active shaper of society [13]

In this context, learning and educational processes are becoming increasingly important, and therefore, a closer look at learning and educational processes is required within transitions. In line with current trends, the new learning pathway will provide new platforms of experience for all people $[12,13]$.

The individual management of transitions and the design of a lifelong adaptation are determined by individual learning processes and institutional frameworks and are, thus, integrated into the process of lifelong learning. In this context, lifelong learning describes the expectations of people to deal with learning and educational processes throughout their entire life course due to social changes in the knowledge society, based on keywords, e.g., industrialisation 4.0, the half-life of knowledge, and more, and therefore, the associated need for action. By focusing on the EU definition, lifelong learning can be understood as "any purposeful learning activity aimed at the continuous improvement of knowledge, skills, and competences" [14]. Accordingly, lifelong learning can be considered as an opportunity and a challenge for all people. Self-management and organisation of each individual is the basic competence. Lifelong learning is defined as an overall process of learning in terms of time, content, and space [15]. Lifelong learning is focused on the entire life span and is no longer limited to the separate stages (e.g., childhood, youth). Learning is a lifelong process, not only the short-term acquisition of new knowledge but also the longer-term engagement with the world. Learning is embedded in life and, thus, also in the biography. The focus is on individual learning in the course of life. Secondly, the concept of lifelong learning refers to all learning processes within and outside educational institu- tions. Thus, learning does not only take place in traditional educational institutions but also in other places of learning and in different formal, non-formal, and informal learning settings. Lifelong learning encompasses all kinds of subjects/objects as well as the development of skills and the change in self-perception and perception of the world [14]. For the pedagogical practice, this consequently implies the orientation toward the design of professional educational offers for the entire life course as well as the fit between lifelong learning and learning offers. The concept focuses on people as 'individual educational subjects' with specific life situations, expectations, and goals (participants-orientation, life-world orientation, and more) $[14,16,17]$.

\subsection{The Concept of Circular Education}

To ensure the necessity of implementing the lifelong learning approach, the authors of this article have developed the circular education approach for awareness raising with regard to pyrolysis, as shown in the diagram below (Fig. 4), in order to achieve the awareness raising concepts for all social as well as individual areas of life.

According to the circular education approach, the life span is divided into a total of 4 dimensions and ranges from earliest childhood to high adulthood. Due to the increasingly blurred boundaries between life stages and ages, these 4 areas are to be understood as dimensions with fluid transitions and not every person passes through each dimension, these can also be skipped or dealt with at a later time. The first dimension covers the period from early childhood to the end of basic education. Within the second dimension is higher education and all related educational formats. Gainful employment and its educational activities are located in the third dimension. The fourth dimension includes all adult education activities, regardless of whether formally, non-formally, or informally acquired. A professional and successful design of educational activities requires that essential core aspects be included in planning, implementation, and evaluation. These framework conditions are examined in more detail below.

\subsubsection{Development of Educational Services for Raising Awareness on Pyrolysis}

Here, the authors propose a concept regarding the development of educational services for raising awareness on pyrolysis (Fig. 5).

Fig. 4: Concept of circular education (VETVocational Education \& Training






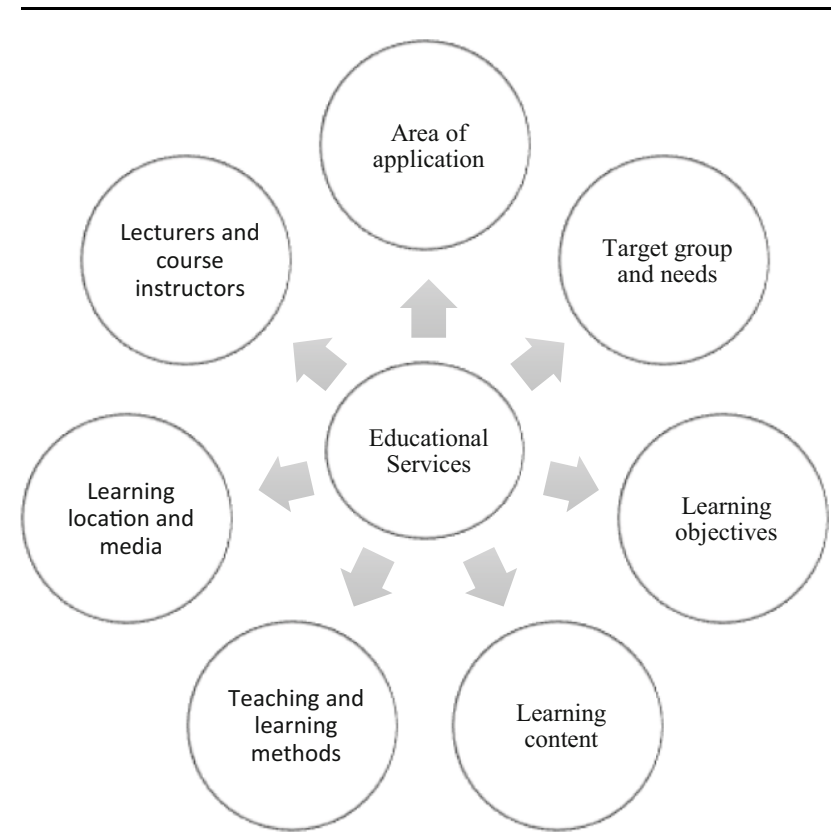

Fig. 5: Concept of educational services

By referring to the concept for the planning of educational services, the following seven aspects should be considered in the conceptualisation of educational initiatives [18-21]. Woschank and Pacher summarise the conditions for successful learning as follows [22]:

- The area of application focuses on the learning content and their applicability and usability towards practical application. The subsequent practical usage of educational services for pyrolysis can be facilitated by pre-structuring and determining specific requirements of the institutional environment and the subjective factors, e.g., the wishes or expectations of the target group as well.

- The target group includes prospective participants who can be defined by certain group characteristics (students, professionals, and more). Yet, these target groups need to be constructed by using a set of specific categories. In addition to socio-cultural, demographic, and economic factors, educational attainment, motivation and learning requirements are also very important. Furthermore, the learning concept should include the lifeworld orientation as well as the learning behaviour of future participants.

- Learning objectives are defined as an interface between external requirements and internal content design. Learning objectives provide information about why these contents are essential to know from a lecturer's perspective. Learning objectives can be structured in terms of time, content, and methods within the framework of micro-didactic planning. On the basis of these objectives, learning outcomes should be formulated to outline what participants should be able to know or to do after a course. In order to ensure the learning success of the participants, the educational services must be aligned to one or more learning objective and learning outcome.
- According to the concept of constructive alignment, the predefined learning objectives and learning outcomes serve as the basis for the further selection of the learning content. The selection of relevant learning content is based on didactical decisions, which can be considered as a compensatory and iterative process. Hereby, Siebert further refers to the term "didactical reduction" [22]. The content should be specifically selected for the participant and situation and, therefore, also adapted toward the wishes, interests, and expectations of the participants. This is necessary because individual as well as collective characteristics are essential for the entire learning success. Further decisions and questions in the planning process, for example the learning location, media, teaching, and learning methods, are based on the previous definition of the content.

- Teaching and learning methods define the type of lecture (e.g., seminar, interactive lesson, and more), the timeframe of the educational service, and the number of hours per lecture. For example, some participants prefer shorter weekly dates, while others prefer to block events. The choice of methods strongly depends on the objectives, the content, and participant-orientations.

- Learning locations are visited for a limited period to learn-consciously or subconsciously. The learning locations, their design, and the entire learning organisation make a significant contribution to learning success. Premises should be functional and coordinated with the methods and are part of the macro-didactic planning. There are again differences and preferences depending on participants, lecturers, and even institutions in the design of these places.

- The selection of lecturers must be based on specific premises, like pedagogical, social, didactic, professional, and interpersonal competencies and qualifications. Previous knowledge or experience with the respective target group could also be an important success factor. Lecturers are considered as a very important component regarding the learning success and overall subjective satisfaction of the seminar participants [23].

\subsubsection{Example: Interactive Societal Learning Concept}

As Fig. 6 illustrates, the interactive societal learning concept for the lab is intended to be intergenerational and freely accessible. The lab should have both a showroom and a space for experimentation opportunities. In the showroom, the respective processes with explanations should be adapted to the respective target group and provided with different colours so that all visitors, children, students as well as adults can orientate themselves even without guided tours. A separate area should be equipped for the experimental opportunities and again be adapted to the respective target group and its characteristics. One part of this area should be freely accessible to all visitors, another should be guided by trained personnel. Furthermore, the interactive societal learning concept should also be a platform for active exchange, such as panel discussions, lectures, or events of 


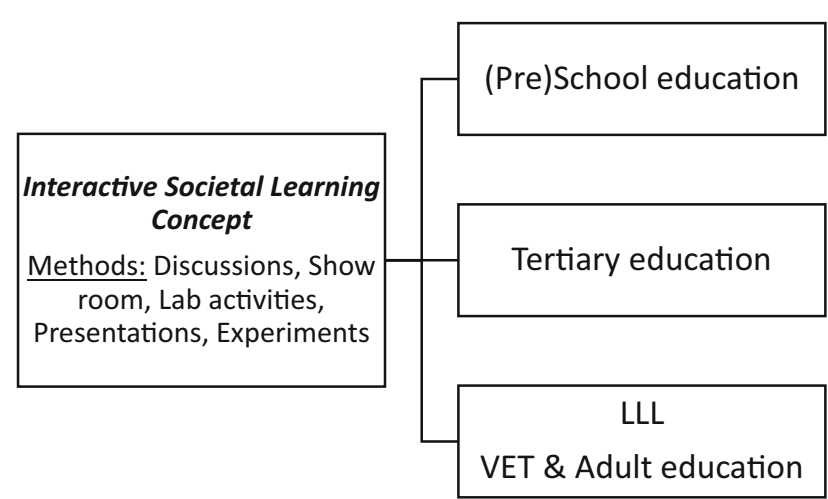

Fig. 6: Interactive societal learning concept (VET Vocational Education \& Training, LLL Lifelong learning)

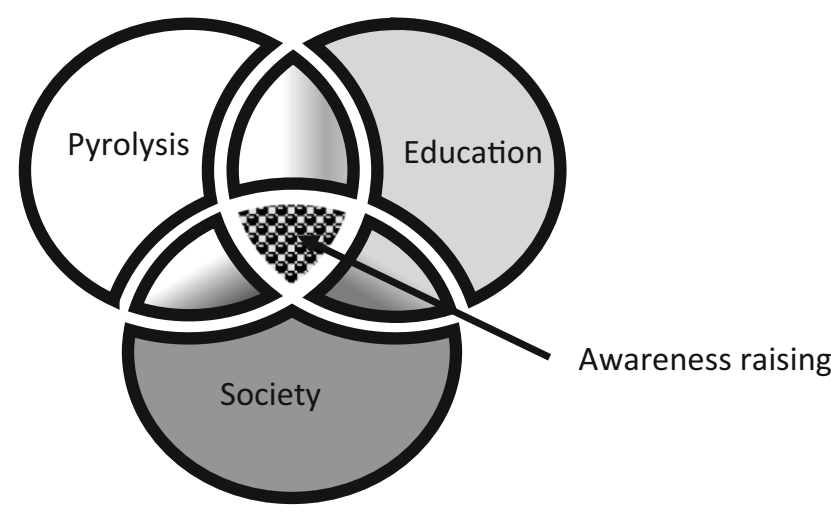

Fig. 7: Awareness raising

any kind around the topic of hydrogen and sustainability. Thus, the interactive societal learning concept should be available as a learning and experience space for the entire society and should, thus, make a significant contribution to raising awareness regarding the further development towards a sustainable society.

\section{Conclusions}

The research and development of new technologies is an indispensable factor for sustainable economic and societal growth. The distance between knowledge transfer outside of the scientific community, however, creates a gap of understanding within the general population. In order to bridge that gap and strengthen the social licence to operate, the amalgamation of technological and wider society educational learning approaches unite to form a holistic front (Fig. 7). As a central element of the European Pillar of Social Rights, the teaching of relevant and up-to-date skills and knowledge is indispensable [24]. Thus, top notch education must be made available to all people to actively and self-confidently make a significant contribution as citizens regarding further developments and the sustainable handling in and with our planet and natural resources.

Funding. Open access funding provided by Montanuniversität Leoben
Open Access This article is licensed under a Creative Commons Attribution 4.0 International License, which permits use, sharing, adaptation, distribution and reproduction in any medium or format, as long as you give appropriate credit to the original author(s) and the source, provide a link to the Creative Commons licence, and indicate if changes were made. The images or other third party material in this article are included in the article's Creative Commons licence, unless indicated otherwise in a credit line to the material. If material is not included in the article's Creative Commons licence and your intended use is not permitted by statutory regulation or exceeds the permitted use, you will need to obtain permission directly from the copyright holder. To view a copy of this licence, visit http://creativecommons.org/licenses/by/4.0/.

\section{References}

1. Bertau, M.; Räuchle, K.; Offermanns, H.: Methanol - die Basischemikalie. Chem. Unserer Zeit, Weinheim: WILEY-VCH Verlag, 49 (2015), pp 312-329, DOI: https://doi.org/10.1002/ciuz.201500689

2. International Energy Agency: Energy Technology Perspectives, Paris: IEA Publications, 2017

3. Fuel Cells and Hydrogen 2 Joint Undertaking: Hydrogen Roadmap Europe, 2019, DOI: https://doi.org/10.2843/341510

4. Abbas, H. F.; Wan Daud, W.M. A.: Hydrogen production by methane decomposition: A review. Int. J. Hydrogen Energy, 35, (2010), pp 1160-1190, DOI: https://doi.org/10.1016/j.ijhydene.2009.11.036

5. Cetinkaya, E.; Dincer, I.; Naterer, G. F.: Life cycle assessment of various hydrogen production methods. Int. J. Hydrogen Energy, 37 (2012), pp 2071-2080, DOI: https://doi.org/10.1016/j.ijhydene.2011.10. 064

6. Noro, A.; Lonza, L.: Electricity carbon intensity in European Member States: Impacts on GHG emissions of electric vehicles, Journal of Transportation Research Part D: Transport and Environment, 64 (2018), pp 5-14, DOI: https://doi.org/10.1016/j.trd.2017.07.012

7. Rau, F.; Herrmann, A.; Dorn, C.; Krause, H.; Sorani Montenegro, Y.; Fino, D.; Trimis, D.: Entwicklung eines autothermen Biogasreformers zur Herstellung von Wasserstoff. 14. Symposium Energieinnovation, Graz: TU Graz, 2016

8. Metz, B.; Davidson, O. R.; De Coninck, H.; Loos, M.; Meyer, L. A. (eds.): IPCC Special Report: Carbon Dioxide Capture and Storage, New York: Cambridge Univ. Press, 2005

9. Schneider, S.; Bajohr, S.; Graf, F.; Kolb, T.: Verfahrensübersicht zur Erzeugung von Wasserstoff durch Erdgas-Pyrolyse. Chemie Ingenieur Technik, Weinheim: WILEY-VCH Verlag, 92 (2020), pp 1023-1032, DOI: https://doi.org/10.1002/cite.202000021

10. Dufour, J.; Gálvez, J. L.; Serrano, D. P.; Moreno, J.; Martínez, G.: Life cycle assessment of hydrogen production by methane decomposition using carbonaceous catalysts. International Journal of Hydrogen Energy, 35 (2010), pp 1205-1212, DOI: https://doi.org/10.1016/j. ijhydene.2009.11.093

11. Mora, H; Pujol-Lopez, F.A.; Mendoza-Tello, J.C.; Morales-Morales, M.R. An education-based approach for enabling the sustainable development gear, Comput. Hum. Behav. 2018. https://doi.org/10.1016/j. chb.2018.11.004

12. Schäffter, O.: Transformationsgesellschaft. Temporalisierung der Zukunft und die Positivierung des Unbestimmten im Lernarrangement, in: Wittpoth, J. (ed.): Erwachsenenbildung und Zeitdiagnose, Bielefeld: Bertelsmann, 2001, pp 39-68

13. Felden, H. v.: Transformationen in Lern- und Bildungsprozessen und Transitionen in Übergängen Transformationen in Lern- und Bildungsprozessen, in: Felden, H. v. et al. (eds.), Denken in Übergängen, Wiesbaden: Springer, 2014, pp 61-84

14. European Commission, Mitteilung der Kommission: Einen europäischen Raum des lebenslangen Lernens schaffen, Brussels: European Commission, 2001

15. Hof, C.: Übergänge und Lebenslanges Lernen, in: Schröer, W. Stauber, B.; Walther, A.; Böhnisch, L.; and Lenz, K. (ed.): Handbuch Übergänge, Weinheim/Basel: Juventa, 2013, pp 394-415

16. Delory-Momberger, C.: Biografisches Lernen, in: Göhlich, M., Wulf, C. and Zirfas, J. (eds.): Pädagogische Theorien des Lernens, Weinheim/Basel: Beltz, 2007, pp 142-152

17. Dausien, B.: Lebenslanges Lernen als Leitlinie für die Bildungspraxis Überlegungen zur pädagogischen Konstruktion von Lernen aus bi- 
ografietheoretischer Sicht, in: Herzber, H. (ed.), Lebenslanges Lernen, Frankfurt am Main: Lang, 2008, pp 151-174

18. Hippel, A. von; Kulmus, C.; Stimm, M.: Didaktik der Erwachsenenund Weiterbildung. Paderborn: utb, 2019

19. Tippelt, R.; Hippel, A. von: Handbuch Erwachsenenbildung/Weiterbildung, 6th ed., Wiesbaden: Springer, 2018

20. Reich-Claasen, J.; Hippel, A. von: Programm- und Angebotsplanung in der Erwachsenenbildung. in: Tippelt R, Hippel A von, (eds).: Handbuch Erwachsenenbildung/Weiterbildung, 6th ed., Wiesbaden: Springer, 2018, pp 1405-1425

21. Nittel, D.: Von der Mission zur Profession? Stand und Perspektiven der Verberuflichung in der Erwachsenenbildung. Theorie und Praxis der Erwachsenenbildung. Bielefeld: Bertelsmann, 2000
22. Woschank, M.; Pacher, C.: Program Planning in the Context of Industrial Logistics Engineering Education, Procedia Manufacturing, 51 (2020), pp 1819-1824

23. Siebert, H.: Didaktisches Handeln in der Erwachsenenbildung: Didaktik aus konstruktivistischer Sicht, 6th ed., Augsburg: Ziel, 2009

24. Tippelt, R.; Reich, J.; Hippel, A.; Barz, H.; Baum, D.: Milieumarketing implementieren, Bielefeld: Bertelsmann, 2008

Publisher's Note. Springer Nature remains neutral with regard to jurisdictional claims in published maps and institutional affiliations. 